\title{
Politeness System Portrayed in Social Media: A Case Study of Facebook Account "Sapawarga Kota Surabaya"
}

\author{
Intan Amalia, Universitas Airlangga \\ Kurnia Asri Prasetyorini, Universitas Airlangga
}

\begin{abstract}
Facebook has become the most effective media used by many people to communicate and to interact. This phenomena used by Surabaya's government to communicate and interact more with its citizen. This research revealed the politeness system used in their Facebook account, Sapawarga Kota Surabaya, by revealing the involvement strategy through their posts. The data is the Facebook status posted in May 2018 as there was Surabaya birthday event. The data then categorized into three main topics; Surabaya birthday, information about Surabaya, and motivational quotes. The involvement strategy could be seen in each topic which consist of notice or attend, membership claiming with the reader, point of view agreement, optimism, giving the nickname, and using similar language or dialect with the reader. The result shows that Facebook account Sapawarga Kota Surabaya use involvement strategy in all of their post with the intention to get friendlier, to eliminate the social distance (-D), and power relation (-P), therefore Surabaya citizen would be more open in channeling their aspirations. This kind of involvement strategy is called as solidarity politeness system which makes Sapawarga Kota Surabaya as government Facebook account the connecting bridge between the governments with Surabaya citizen.
\end{abstract}

Keywords: facebook; involvement strategy; politeness system; Surabaya city

\section{Introduction}

Technology development makes people all around the world use internet all the time. The new 2018 Global Digital suite from We Are Social and Hootsuite report that there are approximately 4 billion internet users. More than 3 billion of them use internet every month, and 9 out of 10 access internet platform or social media from their mobile phone. Social media is the easiest way for people to communicate with other people. One of the most popular social media is Facebook. In March 2017 Facebook's users reach 60 million from 1.94 billion of people all around the world and it increased to 2, 20 billion of users in March $31^{\text {st }}, 2018$. It continues to rise to 20 million of active users per July. And at the end of the year, there will be 2,35 billion of active users monthly (Kallas, 2018). Facebook becomes the most effective and accessible media for every individual or group of people to stay in touch, to interact, and to communicate with other people through pictures, texts, video, attachment, personal messages, group, video call, in spite of the long distance.

Indonesia is nominated as the $4^{\text {th }}$ country having the most of Facebook's users. Up to January 2018, Facebook users in Indonesia have reached 130 million which is four percent of overall users worldwide. This makes Indonesia as having the most Facebook users in Southeast Asia (Septania, 2018). Thus, as one of the big city in Indonesia, with several achievements and rewards which make it acknowledged internationally, Surabaya utilizes Facebook as their media to communicate with Surabaya citizen, as well as in order to keep up with the new technology and the benefit gotten from Facebook. Sapawarga Kota Surabaya is Facebook account owned by Surabaya government since 2011 and operated by Surabaya Communication and Informatics Department. This account is made to interact with Surabaya citizen, to spread the information, to report news and activities happened in Surabaya so it will become the connecting bridge between the government and the Surabaya citizen. 
Research regarding the function of Facebook as a platform to interact and to communicate between the citizen and the government has been done by Park, Lee, Yoo, and Nam (2016). This research focus in analyzing the governments uses Facebook to develop the tourism in their area. The result shows that the use of Facebook by the government not only benefit the domestic tourist but also the other tourist who live far away from the area because the online promotion has already proven to be very successful in developing the tourism. The involvement of Korean local government is fundamental, specifically in promoting the current cultural tourism.

As communication platform between the government and its citizens, language used in social media (Facebook) must be more communicative so it could attract the readers to read the post. Since the purpose of Sapawarga Kota Surabaya is to become the connecting bridge between the government and its citizens, then the face or public image (Scollon, Scollon \& Jones, 2012) made must be different with other social media, or in this case Facebook accounts. The strategy of politeness in every post would shape the public image of Sapawarga Kota Surabaya Facebook account without leaving the Arek culture which is egalitarian, democratic, and open minded by Kadaruslan (in Abdillah, 2007). In communicative study, image is an interesting focus because image would portray the real image that is not shown to others. Through these images it could be seen who is the audience and what role is taken.

Murad, Spiers \& Guirguis (2017) has made a research on communication strategy used in the interaction between pharmacist and their patient. The common strategy used in that communication is by doing solidarity based strategy. Communication strategy required them to admit and support the patient so they would have more positive image of solidarity than negative image. When pharmacist serves the patient, they need to give full attention, get trusted, and respect so they could encourage patient easily to open up about all of their health problems. Once the patient has already opened up themselves, it means they like and trust the pharmacist. In turn, pharmacist would share their knowledge and skills to solve the patient's problem. In this research, pharmacist fulfilled the interactional relation with the patient to strengthen the solidarity and trust which then resulted in a good pharmacist-patient relationship.

The utilization of social media as communication medium is an interesting topic to discuss especially if it is focused on the language study and communication. Previous researches have not discussed about the politeness system consist in social media whereas politeness system could be used to reveal the identity and the purpose of the social media. Thus this research main purpose is to see the politeness system used in Sapawarga Kota Surabaya Facebook account, a government social media account, to its reader or Surabaya citizen through its posts.

\section{Methodology}

This research used descriptive qualitative as the methodology, where according to Locke, Spirduso, and Silverman (1987, in Creswell 2014) stated that qualitative research aims to understand certain social phenomena, interaction, event, role and group. Surakhmad (1978) explained that descriptive research is a research which tries to depict and analyze the data from the collecting, compiling data, and interpreting data stage. While qualitative was used because the researcher does not involve any calculation statistically. This research would focus on finding the politeness system in Surabaya's government engagement in Sapawarga Kota Surabaya Facebook account through the language used in every post. The data would be taken from Sapawarga Kota Surabaya post in May 2018 as there was Surabaya birthday celebration then the data would be separated into groups based on the topic. Lastly this research would find the engagement strategy used by Surabaya's government through its Facebook account Sapawarga Kota Surabaya in order to reveal the politeness system.

\section{Result and discussion}

Most of the contents written on Sapawarga Kota Surabaya's Facebook's posts on May 2018 are about Surabaya's birthday, general information about Surabaya, and motivational 
quotes. Those three have different characters in their writing, for instance in the way the use of the language, emoticon, hashtag and interjection. When they are writing about Surabaya's birthday, they use more than one language which are Javanese, Indonesian, and English. Javanese usually used at the beginning of their post as the opening then followed by Indonesian. Even sometimes these languages are mixed in one sentence alternately. While English often used in the closing statement but the portion is not as much as Javanese and Indonesian. People must select a particular code whenever they choose to speak, and they may also decide to switch from that code to another or to mix codes even within sometimes very short utterances (Wardhaugh \& Fuller, 2015). Emoticon is also used in order to express the emotion about the post. Regarding this topic, they always use \#Surabaya725 as the hashtag to make it convenient for the reader when searching for the related information. On the other hand, the post about general information about Surabaya sometimes delivered in formal variation and does not always use Indonesian, occasionally the admin of the account code mixed the language with English. Moreover, the hashtag used is varied based on the context of the post. Some of the posts regarding that topic are still using emoticon though it is not much. Lastly the motivational quotes are written every morning before other posts using Indonesian without any emoticon and adding the \#morningquotes at the end of the post as the hashtag. In addition, this facebook account also use interjections such as eitsss, yuk, yup, and lho. Interjection is used as a linguistic sign used by it, which can express something related to the human mentality (Wierzbicka, 2003). Referring to the context of the post, eitsss functioned as warning sign, which is can be seen in "Eitsss ada banyak acara lain juga lo lur!". The post intends to warn the citizen to not miss the other events beside the main event held. On the other hand, $y u k$ is the interjection in the Indonesian language that has the same meaning with ayo which means that the speaker wants to invite the other person to do something as illustrated in "Yuk ajak teman, saudara, keluarga, pacar, mantan pacar, gebetan, mantan gebetan, semuanya". In contrast, yup is an interjection that is usually used by Indonesian to justify something. It means that the speaker agrees with the other person as illustrated in "Yup, bener!" Furthermore, lho is an interjection that usually used to express confusion. However, referring to the context of the post, lho is functioned as an interjection to emphasize information, which displayed in "Dalam acara pagi ini Bu Risma juga nari bareng teman-teman Papua lho".

In order to make Surabaya's reader interested with this Facebook account content, this account is using its involvement strategy. The involvement strategy can be in any kind of forms. The writer could show their involvement by contributing to the communication. The writer could also show their involvement by supporting the reader's point of view and making sure the reader believes that the writer has strong relation with them. This research found out that this Facebook account Sapawarga Kota Surabaya used some of the involvement strategies. These strategies are used by Sapawarga Kota Surabaya as the writer (speaker) and the social media reader (hearer) in every post made about Surabaya's birthday, general knowledge on Surabaya, or motivational quotes. The strategies used are in form of notice or attend, membership claiming with the reader, point of view agreement, optimism, giving the nickname, and using similar language or dialect with the reader, which elucidated in 16 data as follows:

(1) Tetap tenang seperti biasa.

(Stay calm as always)

(2) Terimakasih ya dulur sudah tertib nonton selama pawai berlangsung. (Thank you pals for being organized while the festival was held)

(3) Dulur ada yang tadi ikut pawai parade budaya dan bunga? Atau ada yang melambaikan tangan juga ke peserta pawai? Gimana? Seru banget kan lur! (Hey, is there any of you joining the culture and flower festival? Or is there anyone who waves their hands to the festival participant? How was it? It was fun, wasn't it Pals!)

(4) Jangan sampai kita ikut membantu sebar hasil kejahatan para penyebar terror. 
(5) Seru banget kan lur!

(it was fun, wasn't it pals?)

(6) Semoga Surabaya tetap menjadi kota yang menyayangi seluruh warganya, menjadi kota yang mendunia, dan juga kota yang ramah anak dan lingkungan.

(May Surabaya become the city everyone love, the worldwide city, and the city which is save for children and environment)

(7) Hari ini mulai masuk sekolah lagi ya dulur.

(Today is the $1^{\text {st }}$ day of school, right pals?)

(8) Simak info berikut ya lur.

(Check out the following news, pals)

(9) Halo rek!

(Hey, Pals!)

(10) Siap memberangkatkan peserta pawai.... Wes siap lur?

(11) Simak video yang berisi harapan dan doa dari bu risma ini ya lur. Sugeng ambal warsa Suroboyoku

(12) Sampai jumpa luurr... See you there.

(13) Selamat Hari Raya Waisak 2562 BE 2018. Sabbe Satta Bhavantu Sukhitatta.

(14) Nggak hanya itu lho lur.

(15) Ada yang belum bisa move on dari parade bunga dan budaya kemarin?

(16) Dino iki Pasar Malam Tjap Toendjoengan bakal dibuka secara resmi dan bakal digelar sak ulan full.

The involvement strategy must be used by the writer in order to make the reader interested with the content. The writer could show their attention, interest, sympathy, even agreement with the reader. This research found there are some Sapawarga Kota Surabaya's Facebook contents, a Surabaya government official account, showing attention to the reader. The first datum is the post made after there were bombing incident happened in Surabaya. The sentence Tetap tenang seperti biasa (Stay Calm as always) is prove that Surabaya's government is concerned about Surabaya citizen's activity by telling them to do their activity as usual and believe the government would handle the incident well. The second datum was posted to show Surabaya's government appreciation to the citizen because they behaved organize in Surabaya Vaganza 2018 flower festival. This is the involvement strategy used to show that Surabaya's government really gives attention to the citizen so the citizen feels closer and appreciated. The last datum shows that the government give attention by asking many questions or voluble. Sapawarga Kota Surabaya's Facebook account uses voluble as their involvement strategy to make them looks friendlier and approachable. The first, second, and third data shows notice or attend involvement strategy.

Claiming the reader membership with the writer is one of the involvement strategy commonly used in communication. This strategy makes the writer and the reader become closer because the writer make it as if they are one of the reader. This is shown by the using of pronoun kita (We) in the post. According to online dictionary KBBI 5 the word kita is the pronoun used to also include self and others. It means Sapawarga Kota Surabaya facebook account, Surabaya's government representative, is trying to claim membership of Surabaya citizen. The fourth datum was written when there was a bombing terror which made all people become restless. With the using of kita, the government is asking the Surabaya citizen to keep calm and not easily provoked by news which are not always saying the truth so they could make the situation more conducive.

The fifth datum was made to discuss about the excitement in Surabaya Vaganza 2018 culture and flower parade as the pre-celebration of Surabaya birthday. This parade was joined by various group of people including the government and amusement park's group who are showing their creativity in decorating the car's parade with many kinds of flower. Some of them also showed various traditional dances and amusing costume based on their own theme. To make it 
more exciting, one of the amusement park offered a free entrance ticket for those who took a picture with the parade as the background and post it on social media. From the fifth datum, utterance Seru banget kan lur! written bySapawarga Kota Surabaya Facebook account is trying to agree on Surabaya's people opinion that Surabaya Vaganza 2018 culture and flower parade is really fun and exciting.

Becoming optimistic is also one of the ways in involvement strategy to get closer to the reader. Showing the positive hope and becoming optimistic could build up trust between the writer and the reader. The sixth datum is a post about the writer of Sapawarga Kota Surabaya Facebook account's prayer for Surabaya and its people. This post is uploaded at the same time as Surabaya's $725^{\text {th }}$ birthday on $31^{\text {st }}$ May. This post is another involvement strategy done by Sapawarga Kota Surabaya Facebook account to build up Surabaya citizen's optimism as there was bombing incident previously which made them become restless. With this post, Surabaya government hoping in the future Surabaya will always be the most pleasant and safest city to reside in regarding races, tribes, and religions.

Sapawarga Kota Surabaya uses kinship name in some of their posts in May 2108 to address Surabaya citizen; there are dulur, lur, and rek. These are used by Sapawarga Kota Surabaya, which belongs to Surabaya's government, to show the close relation between the government and Surabaya citizen. The seventh datum, dulur means brother in Javanese (Harjawiyana \& Supriya, 2009). As well as the eight datum, lur is the same as dulur. These words, dulur and lur, are used to show the kinship also the positive politeness of Surabaya government in order to become friendlier with Surabaya citizen (Jauhari \& Sugiri, 2012). They use Javanese instead of Indonesian because those address terms are more polite and more kin than using saudara from Indonesian. In the ninth datum, they used rek from arek to address Surabaya citizen. Boedhimoertno (2003) explained that arek has a wide range of definitions; it does not always use to address the kids but also can be used to address the adults. According to online dictionary KBBI, the word arek is used to address the same age friends or from the elder to the youngsters. The word rek is the iconic terms from Surabaya to address others and become the identity of Surabaya's culture.

The using of the reader's language or dialect as one of the involvement strategy by the writer because it is not only the social acts which involve others but also as personal acts made to build identity shown to others (Le Page, 1997). This research found there is some switch and mixed code used by Sapawarga Kota Surabaya. Switch code can be seen in the tenth datum, Indonesian to Javanese vernacular language variation (ngoko). Meanwhile,the eleventh datum is using Javanese formal and polite language variation (krama inggil). In the twelfth datum there is also a switch code from Indonesia to English, while in the thirteenth datum the switch code is from Indonesian to Hindi. There is mixed code in the fourteenth datum, Indonesian and Javanese, Indonesian and English in the fifteenth datum, and a mixed code between Indonesian, Javanese, and English in the fifteenth datum. All of these are the form of situational code-switching (Blom \& Gumperz, 1972). The use of variant dialects in many Sapawarga Kota Surabaya's post in Facebook is one of the cultural forms of Surabaya, Arek culture. The development of Arek culture cannot be separated from the existence of villagers' community (Abdillah, 2007). Each individual of this community is using variant of language and dialects in communicating with each other. According to Djupri (2008), Arek uses Indonesian as the formal language, community language such as Chinese or Maduranesse in certain community or ethnic group, and Javanese with Surabayan dialect or Suroboyoan in their daily activity (Abdillah, 2007). By using Suroboyoan the speaker would feel more confident, looks friendlier, and feels more egality (Djupri, 2008). Javanese and Indonesian are chosen because it shows how government use the common language used by most people or called as convergence (Giles, 2007) to shorten the distance between the government and its people.

Social stratification is a term used to refer to any hierarchical ordering of groups within a society especially in terms of power, wealth and status (Trudgill, 2000). Government as the administrator of public policy made them ranked higher than its citizen in terms of social 
stratification. Thus, social distance and power relation might occur in the interaction between the government and the citizens. However, Sapawarga Kota Surabaya shows more egaliter relationship with the citizens through the use of involvement strategies which categorized as positive politeness since it is emphasizing more on the closeness between the writer and the reader by Brown and Levinson (in Sharifian, 2014). The characteristics of communicative style status posted by Sapawarga Kota Surabaya is in line with the characteristics of solidarity face system proposed by Scollon and Scollon (2012). The communicative style status shows neither distance nor power difference or formulated as $-D$ and $-P$. Hence, those characteristics show high level of involvement politeness strategies, where both participants positioned themselves in equal level and close to one another. Consequently, the absence of power difference and social distance portrayed through the use of involvement strategies reflected in the posts of Sapawarga Kota Surabaya made the citizen feel free to channeling their aspirations.

\section{Conclusion}

This research has found three main topic commonly discussed by Sapawarga Kota Surabaya; Surabaya's birthday, general information related with Surabaya, and motivational quotes. Those three have different characters in their writing, for instance in the way the use of the language, emoticon, and hashtag. Moreover, interjection was also found to emphasize the arguments' expression in various ways. The result revealed 16 involvement strategies used in each of the topic which later categorized into notice or attend, membership claiming with the reader, point of view agreement, optimism, giving the nickname, and using similar language or dialect with the reader. These are done by Sapawarga Kota Surabaya to eliminate the social distance (-D) and power relation (-P) in order to be more approachable to Surabaya citizen. The highest involvement strategy used is the solidarity politeness system which makes Sapawarga Kota Surabaya.

\section{References}

Sapawarga

Kota Surabaya.

Available

at

https://www.facebook.com/pg/sapawargakotasurabaya/about/?ref=page_internal.

(Accessed 2 April, 2018).

Abdillah, A. 2007. Budaya arek Suroboyo: sebuah kajian terhadap awal eksistensinya melalui konteks perubahan sosial komunitas kampung surabaya. Surabaya: Universitas Airlangga.

Blom, J. P., \& Gumperz, J. J. 1972. Social meaning in linguistic structures: code-switching in Norway (In Gumperz, John J. \& Hymes, Dell (ed.). New York: Holt, Rinehart and Winston.

Boedhimoerdono. 2003. Jalan panjang menuju kota pahlawan. Surabaya: Pusura.

Brown, P., \& Levinson, S. C. 1987. Politeness: some universals in language usage. Cambridge: Cambridge University Press.

Creswell, J. W. 2014. Research design: qualitative, quantitative, and mixed methods approach. UK: Sage Publication.

Djupri, M. 2008. Kamus Suroboyoan Indonesia. Surabaya: Henk Publika.

Giles, H., \& Ogay, T. 2007. Accomodation Theory: Communication, Context, and Consequences. In Whaley, B \& Samter, W (eds.). Explaining Communication: Contemporary Theories and Exemplars. Mahwah, NJ: Lawrence Erlbaum Associates.

Harjawiyana, H., \& Supriya, T. 2009. Kamus Unggah-Ungguh Basa Jawa. Yogyakarta: Kanisius.

Jauhari, E., \& Sugiri, E. 2012. Kesantunan Positif dalam masyarakat etnik tionghoa di Surakarta: Kajian Etnopragmatik. MOZAIK: Jurnal Ilmu Humaniora, 12 (2), 105-121.

Top 15 most popular social networking sites and apps. Available at https://www.dreamgrow.com/top-15-most-popular-social-networking-sites/. (Accessed 12 June, 2018). 
KBBI Daring. (n.d.). Available at https://kbbi.kemdikbud.go.id/entri/are. (Accessed 12 June 2018).

Digital in 2018: world's internet users pass the 4 billion mark. Available at https://wearesocial.com/blog/2018/01/global-digital-report-2018. (Accessed 12 June 2018).

Le Page, R. B. 1997. The evolution a sociolinguistic theory of language. In Coulmas, F (ed.), The Handbook of Sociolinguistics. Oxford: Blackwell.

Murad, M. S., Spiers, J. A., \& Guirguis, L. M. 2017. Expressing and negotiating face in community pharmacist-patient interactions. Research in Social and Administrative Pharmacy, 13 (6), 1110-1126.

Park, J. H., Lee, C., Yoo, C., \& Nam, Y. 2016. An analysis of the utilization of facebook by local korean governments for tourism development and the network of smart tourism ecosystem. International Journal of Information Management, 36 (6), 1320-1327.

Scollon, R., Scollon, S. W., \& Jones, R. H. 2012. Intercultural communication a discourse approaches $\left(3^{\text {th }}\right.$ ed.). UK: Wiley-Blackwell.

Indonesia, pengguna facebook terbanyake ke-4 di dunia. Available at https://tekno.kompas.com/read/2018/03/02/08181617/indonesia-pengguna-facebook-ter banyak-ke-4-di-dunia. (Accessed 6 June 2018)

Sharifian, F. 2014. The Routledge Handbook of Language and Culture. New York: Routledge.

Surakhmad, W. 1978. Dasar dan teknik research: Pengantar Metodologi Ilmiah. Bandung: Tarsito.

Trudgill, P. 2000. Sociolinguistics: An introduction to language and society. UK: Penguin.

Wardhaugh, R., \& Fuller, J. M. 2015. An introduction to sociolinguistics. UK: Wiley Blackwell.

Wierzbicka, A. 2003. Cross-cultural pragmatics the semantics of human interaction. Berlin: Mouton de Gruyter. 